特集 周産期医学の進歩

順天堂医学 $43(4)$

p. $548 \sim 550$ (1998)

\section{胎児診断された小腸閉鎖の一例**}

出生前診断の有用性について

\title{
A case of small bowel atresia
}

The value of prenatal diagnosis:

山高篤 行*

ATSUYUKI YAMATAKA,M.D.
宮 野

岩下 公 江*
武*

キーワード：出生前診断, 小腸閉鎖

Key words : prenatal diagnosis, intestinal atresia

\section{緒言}

胎児超音波検査の発達に伴い，横隔膜へルニ ア・臍帯へルニア・腹壁破裂・小腸閉鎖など様々 な小児外科疾患が，出生前に診断されるようにな り，母体や胎児に対する対応が周産期から速やか になされ，これら小児外科疾患の治療が大きく変 化してきている1）2．

われわれは，腸閉鎖を発生したと考えられる時 期から分婏に至るまで, 経時的な胎児超音波観察 が施行された回腸閉鎖の一例を経験したので，こ の症例をもとに先天性腸閉鎖症における胎児診断 の有用性を報告する。

\section{症例}

1 回経産, 29 歳の健康な母親. 妊娠 31 週 2 日の 超音波検査にて胎児腹水を初めて指摘された ( 図-1)。1週間後の 32 週 2 日でも, 腹水は存在

*順天堂大学医学部外科学教室小児外科学講座

Department of Pediatric Surgery, Juntendo University School of Medicine, Tokyo, Japan **第282回順天堂医学会学術集会 [Sept. 18, 1997 開催〕 [Jan. 5, 1998 原稿受領]
し，同時に胎児腸管の拡張が出現しており，腸管 内径は $13 \mathrm{~mm}$ と計測された (図-2).34週2日・ 36 週0日·37 週0日の観察では, 腹水は徐々に減 少し, ほぼ消失したものの, 腸管径は拡張し続け, 37 週には $22 \mathrm{~mm}$ に達した (図-3)。消化管の拡 張の指摘と同時に産科のみでなく, 小児外科・新 生児科も母体・胎児管理に参加し，37週4 日に誘 発による経腟分婏にて $3075 \mathrm{~g}$ の男児を出生した. 回腸閉鎖の診断のもと, 生後 2 時間で開腹手術が 施行された。開腹時, Treitz 勒帯より $85 \mathrm{~cm}$ 遠位

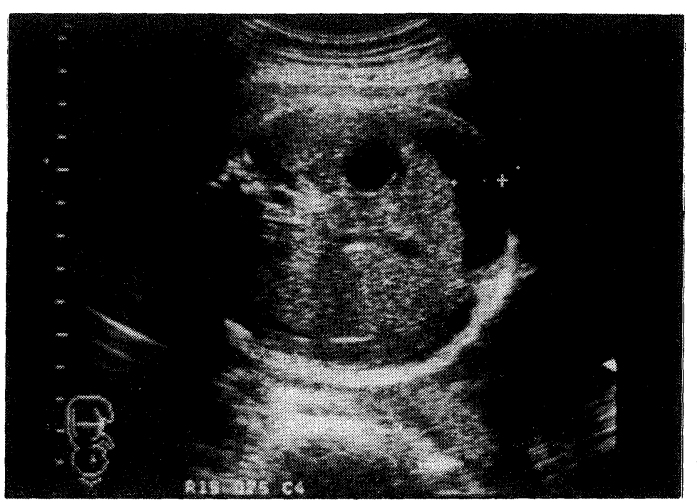

図-131週2日胎児超音波 胎児腹水が指摘された 
側に 4 力所の多発閉鎖を認め, 回腸閉鎖の診断は 確定されたが，同時に口側遠位端に穿孔を認め， 胎便性腹膜炎を併発していた（図-4)。穿孔は新 しいものと考えられ癒着も軽度であったが，多発 閉鎖部切除・腸瘦造設術を施行, 2 力月後に腸瘻 閉鎖術を施行した。

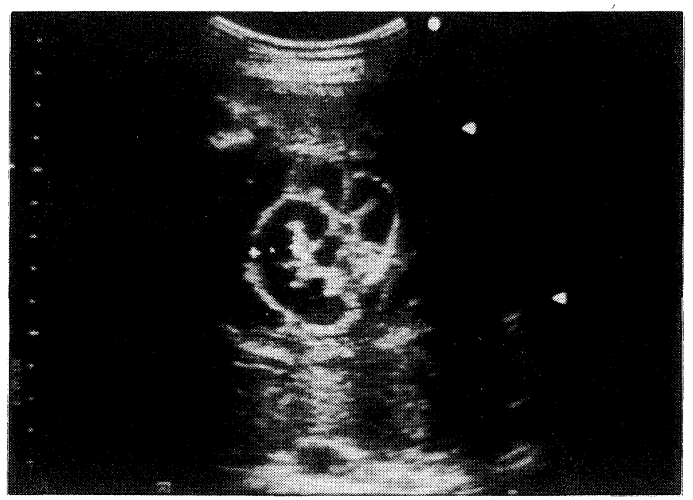

図-2 32 週 2 日胎児超音波 胎児腸管の拡張 $(13 \mathrm{~mm})$ を認めた

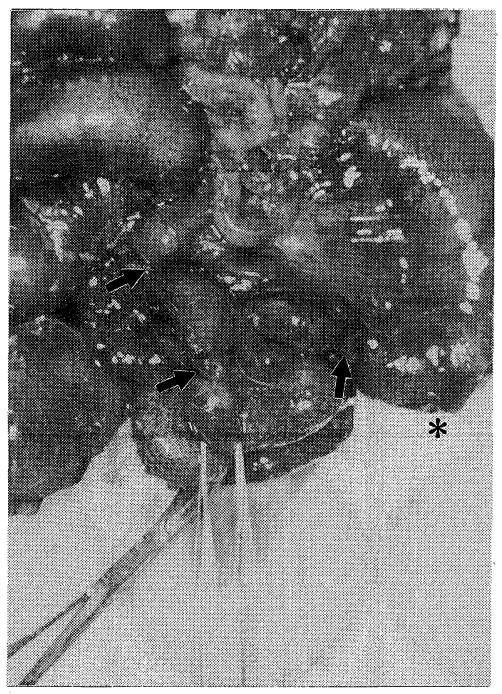

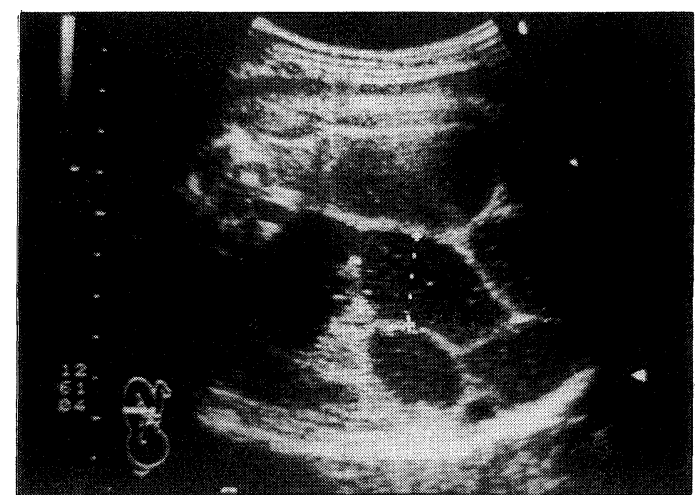

図-3 37 週0日胎児超音波 胎览腸管の拡張は $22 \mathrm{~mm}$ に達した

図-4 術中写真およびそのシェーマ

多発閉鎖 ( 矢印) を認める。口側遠位端に穿孔部 $(*)$ を認める 
術前に脱水・循環不全の補正をまず行わなければ ならなかった．また，腸閉鎖に消化管穿孔が生じ ていた場合には, 開腹時すでに 24 時間以上経過 していることも少なくなく, 既に穿孔部より細菌 が腹腔内に侵入，患児は細菌性腹膜炎から敗血症 を併発し, 救命率は低かった。しかしながら, 出 生前診断により, 腸閉鎖の治療は大きく変わって きている1）3．まず，患児の計画的な周産期管 理・治療方針の早期確立が可能となり, 出生後, 速やかに開腹手術を行えるようになった，すなわ ち, 患児が脱水・呼吸循環不全に陥る前に, 手術 が行えるようになった。 また，われわれの症例の ように消化管穿孔を生じていたような症例でも， 生後数時間のうちに開腹術が施行されるため, 穿 孔部はまだ無菌であるため胎便性腹膜炎を呈する のみであり，患児が敗血症に陥る危険が極めて少 なくなった。このように出生前診断症例では，一 般に患児の術前状態が良く, 術後の回復も速やか であることが多く, 今後出生前診断症例の増加に 伴い，予後はより良好なものになっていくと思わ れる.

本症例における腸閉鎖の発生時期に関しては， 胎児腹水が初めて認められた時期と深く関係して
いると考えられ，腸管の血行障害が腹水として反 映されたものと推察される。また，胎児超音波 37 週0日では, 胎児腸管の拡張が観察されるのみ で，消化管穿孔の所見を認めていないことから， 回腸穿孔は妊娠 37 週0日から分婏日の 37 週 4 日 までの期間に発生したと考えられる。もう少し早 い分婏を行っていれば, 回腸穿孔を回避できてい た可能性を考えると, 分婏時期に関して考えさせ られる症例であった。

\section{文献}

1) Yamataka A and Pringle $K: A$ case with duodenal duplication cyst: Prenatal diagnosis and surgical management. Fetal Diagnosis Therapy (in press).

2) Dykes E : Prenatal diagnosis and management of abdominal wall defects. Semi Ped Surg, $1996 ; 5: 90 \sim 94$.

3) Weissman A and Goldstein I : Prenatal sonographic diagnosis and clinical management of small bowel obstruction. Am J Perinatology, $1993 ; 10: 215 \sim 216$. 